\title{
Principles of innovative reproduction strategic planning of the enterprises fixed assets in rock- et and space industry
}

\author{
Andrey Boyko ${ }^{1,2}$, Vladislav Kukartsev ${ }^{1,2, *}$, and Alena Stupina ${ }^{1,2,3}$ \\ ${ }^{1}$ Siberian State Aerospace University ,Krasnoyarskiy Rabochiy Ave., 31, Russian Federation, \\ Krasnoyarsk, 660037 \\ ${ }^{2}$ Siberian Federal University Svobodny Ave., 79, Russian Federation, Krasnoyarsk, 660041 \\ ${ }^{3}$ Krasnoyarsk State Agrarian University, Mira Ave., 90, Russian Federation, Krasnoyarsk, 660049
}

\begin{abstract}
The principles of planning the reproduction of fixed assets of the rocket and space industry enterprises are investigated, taking into account the features of their activities and the requirements for strategic planning.
\end{abstract}

\section{Introduction}

In the 1990s, there was a qualitative change in the nature of reproduction of fixed productive assets (FPA). The aging process of fixed assets (especially the active part) was determined by the unacceptably low rate for modern economy of disposal of obsolete equipment and the commissioning of the new equipment. Rocket and space industry (RSI) is one of the leaders in the percentage of deterioration of FPA (60\%), while the annual pace of renovation of fixed assets decreased to less than $1 \%$ (the norm is $7-10 \%$ ). In the whole enterprise of space-rocket industry depreciation of fixed assets of main activities is 56-57 percent, and machinery and equipment is approximately 77 percent $[1,2]$.

In recent years, there has been an increase in budgetary allocations for the development of the RSI, with an increase in their investment focus. Against this background, the desire of the leadership of the RSI to conduct a massive technical and technological rearmament of enterprises is natural. But the renewal of the basic production assets of enterprises of the military-industrial complex (MIC) is the task of the scale of financing is quite comparable with the state armament program. The topical issue is the problem of minimizing costs and increasing the efficiency of using budgetary funds.

\footnotetext{
*Corresponding author: vlad saa 2000@mail.ru
} 


\section{Literature review}

The development strategy of the rocket and space industry until 2015 envisages an increase in production volumes in $2025-220 \%$ to the level of 2015 . The share of innovative products in the total volume of the rocket and space industry in 2025 will be $55 \%$ versus $35 \%$ in 2015. The share of RSI products in the world production market of rocket and space technology should reach $15 \%$ by 2025 . The objectives of the strategy are to create a rocket and space complex that meets modern requirements for military security, increase the share of domestic companies in the world market of rocket and space products and services, and preserve the scientific potential of the rocket and space industry $[1,3]$.

One of the goals of the strategy is to overcome the "significant technological gap from the developed countries", as a result of which the share of new industrial equipment (up to ten years) in the industry should increase to $33-35 \%$ from the current $3 \%[1,3]$.

Thus, it is necessary to improve tools and methods for strategic management of the reproduction of FPA enterprises because of many reasons such as innovative development of the RSI, the volatility of the functioning economic environment and the high level of uncertainty of the decisions-making $[4,5,6]$.

The most important component of the methodology of strategic planning of innovative reproduction of FPA are the methodological principles, which are the initial provisions, the basic rules for the formation and justification of plans. They ensure the focus, integrity, certain structure and logic of the strategic plans development.

The current state of the rocket and space industry, existing tendencies, revealed features of the activity and the goals of its development allowed us to formulate the principles of innovative reproduction of FPA [7, 8]. Its implementation is primarily related to the necessity of improved of methodology and tools for planning innovative reproduction.

The methodological principles of planning innovative reproduction of FPA should take into account the existing development features and objectives of the RSI enterprises, rely on the theoretical provisions and identified regularities, establish general rules for the development and effective operation of this subsystem. The formation of a set of principles for the planning of innovative reproduction of FPA in the enterprise makes it possible to carry out a planning methodology that adequately reflects the real interactions and features characteristic of the research object $[9,10]$. In this regard, during the conducted research we have studied and analyzed the main principles of intrafirm planning offered by various specialists. The composition of the principles considered by different authors is not the same, which is understandable, since it is determined on the basis of the features of the research objects, the level and objectives of the planning. In some cases, these differences are caused by the fact that the content of a certain principle of one author is expressed by two and more principles of another author. Thus, the content of the principles of unity and coordination of M.M. Alekseeva [7] is expressed in the principle of complexity of M.I. Bukhalkova, V.I. Borisevitch [8], G.A. Kandaurova, N.N. Kandaurova, A.I. Ilyin [9] and some others.

The study and analysis of the content of the planning principles considered by various authors is certainly of theoretical and practical interest, but it can hardly be exhaustive from the point of view of forming the principles for planning the innovative reproduction of the FPA of the RSI enterprises. Undoubtedly, the existing methodological developments should be taken into account, but the composition of the principles and their content should be primarily determined on the basis of the existing features of the enterprise operations, the requirements for the planning process for the reproduction of the FPA of the RSI enterprises [11]. 


\section{Problem statement}

In accordance with the features of the activity and planning requirements, the main methodological principles of strategic planning for innovative reproduction of FPA enterprises of the Defense Industrial Complex (DIC) were determined (Table 1).

The content of individual principles was concretized according to the revealed patterns of reproduction of the FPA of the RSI enterprises, as well as the forms of their manifestation [12]. Along with this, several principles were added, the content of each principle was disclosed. Among them are balance, the account of scientific and technical progress, adaptability, identities. Further, let us look at the content of the formulated principles for the planning of innovative reproduction of the FPA enterprises of the RSI [13].

Table 1. Features of the activities of enterprises of the RSI, the requirements and methodological principles of strategic planning of innovative reproduction of FPA

\begin{tabular}{|c|c|c|c|}
\hline \# & $\begin{array}{c}\text { Features of the RSI enter- } \\
\text { prises activities }\end{array}$ & $\begin{array}{l}\text { Requirements for the planning of } \\
\text { innovative FPA reproduction of RSI } \\
\text { enterprises }\end{array}$ & $\begin{array}{l}\text { Methodological princi- } \\
\text { ples of strategic plan- } \\
\text { ning }\end{array}$ \\
\hline 1. & $\begin{array}{l}\text { High science-intensive, high } \\
\text { manufacturability of pro- } \\
\text { duction processes and prod- } \\
\text { ucts, high innovative capa- } \\
\text { bilities }\end{array}$ & $\begin{array}{l}\text { Planning should be aimed at ensuring } \\
\text { innovative reproduction of FPA }\end{array}$ & $\begin{array}{l}\text { Scientific validity, con- } \\
\text { sideration of scientific } \\
\text { and technical progress, } \\
\text { purposefulness, dyna- } \\
\text { mism, identity }\end{array}$ \\
\hline 2. & $\begin{array}{l}\text { Activity dependence of the } \\
\text { RSI enterprises on the state } \\
\text { order }\end{array}$ & $\begin{array}{l}\text { Planning should be focused on ensuring, } \\
\text { first of all, the output of products of the } \\
\text { State Defense Order (SDZ) }\end{array}$ & Relevance, focus \\
\hline 3. & $\begin{array}{l}\text { Increasing role of conver- } \\
\text { sion in ensuring sustainable } \\
\text { RSI enterprises develop- } \\
\text { ment and financing innova- } \\
\text { tion }\end{array}$ & $\begin{array}{l}\text { Planning should be oriented towards } \\
\text { ensuring the release of SDZ and civilian } \\
\text { products }\end{array}$ & $\begin{array}{l}\text { Optimality, complexity, } \\
\text { balance, flexibility }\end{array}$ \\
\hline 4. & $\begin{array}{l}\text { Integration of RSI enterpris- } \\
\text { es }\end{array}$ & $\begin{array}{l}\text { Planning should be focused on the con- } \\
\text { centration of investment resources to } \\
\text { the problems solvent of reproduction } \\
\text { FPA }\end{array}$ & $\begin{array}{l}\text { Integrability, complexi- } \\
\text { ty, decomposition }\end{array}$ \\
\hline 5. & $\begin{array}{l}\text { iqueness and } \\
\text { ducts }\end{array}$ & $\begin{array}{l}\text { Planning should be aimed at reducing } \\
\text { the costs of FPA reproduction }\end{array}$ & $\begin{array}{l}\text { Optimality, efficiency, } \\
\text { criteriality }\end{array}$ \\
\hline 6. & $\begin{array}{l}\text { Duration of the production } \\
\text { cycle }\end{array}$ & $\begin{array}{l}\text { Planning should ensure a shorter dura- } \\
\text { tion of the production cycle through the } \\
\text { introduction of more productive equip- } \\
\text { ment }\end{array}$ & $\begin{array}{l}\text { Efficiency, } \\
\text { adaptability }\end{array}$ \\
\hline 7. & $\begin{array}{l}\text { Continuous increase of re- } \\
\text { quirements to quality, relia- } \\
\text { bility, resource of products, } \\
\text { as well as to production } \\
\text { culture }\end{array}$ & $\begin{array}{l}\text { Planning the reproduction of FPA } \\
\text { should ensure the improvement of } \\
\text { quality, reliability of products }\end{array}$ & $\begin{array}{l}\text { Accuracy, } \\
\text { adaptability }\end{array}$ \\
\hline 8. & $\begin{array}{l}\text { Small number of products in } \\
\text { production }\end{array}$ & $\begin{array}{l}\text { Planning should include: computeriza- } \\
\text { tion, flexibility and mobility of produc- } \\
\text { tion and renewal of the technological } \\
\text { park of equipment }\end{array}$ & $\begin{array}{l}\text { Dynamism, flexibility, } \\
\text { adaptability, identity }\end{array}$ \\
\hline 9. & $\begin{array}{l}\text { Various organizational and } \\
\text { legal forms of enterprises of } \\
\text { the RSI }\end{array}$ & $\begin{array}{l}\text { Planning should focus on expanding the } \\
\text { forms of sources of investment re- } \\
\text { sources of reproduction of FPA }\end{array}$ & $\begin{array}{l}\text { Purposefulness, optimal- } \\
\text { ity, decomposition, effi- } \\
\text { ciency, flexibility }\end{array}$ \\
\hline
\end{tabular}


1. Scientific validity is based on the consideration of existing laws and trends in the development of reproduction of FPA. Its meaning is the scientifically based use of tools and methods for decisions-making that are of significant importance for the developed plans for innovative reproduction of FPA.

2. Accounting for scientific and technical progress is to take into account the continuous change, development and improvement of the means of labor, technology and the organization of production.

3. Complexity is to link the plans for the reproduction of FPA by forms (natural and value), in the stages of the process of reproduction (attraction, use and restoration) and by reproduction levels (social and individual).

4. Continuity defines the planning process as continuous, when another new plan comes to replace one completed plan, and the second one is replaced by a third one, and so on. In the process of FPA reproduction is continuous. It includes three consistent stages: the transformation of money-capital into productive, productive into commodity and commodity into money.

5. Optimality is to find the best version of the plan for the reproduction of FPA from the whole set of permissible solutions based on the use of economic and mathematical models [14].

6. Relevance has two levels. The first means the need to take into account the most significant factors when developing a plan for the reproduction of FPA. The second involves more details and the search for optimal solutions for those plans that are essential for achieving the goals and objectives of planning.

7. Flexibility assumes that the plans and the planning process for innovative reproduction of the FPA could change its direction due to unforeseen circumstances.

8. Purposefulness involves the definition and structuring of goals and objectives that correspond to the subject of research, taking into account the features of the object and providing solutions to identified problems. It is necessary to distinguish the development goals and the functioning of the economic system. A feature of innovative reproduction is the predominance of the goal of development and, accordingly, the establishment of development plans.

9. Criterionality is to develop a criteria or several criteria that reflect the extent to which local goals and objectives of innovative reproduction of FPA are achieved, as well as global ones $[15,16]$.

10. Decomposability is the need to structure the goals and objectives of planning the reproduction of FPA. This principle can proceed as a principle of dynamism in the decomposition of the process of reproduction of FPA in time along the stages of circulation and forms of reproduction, and in the principle of hierarchy in the decomposition of the process according to the levels of reproduction of FPA.

11. Dynamism is the need to take into account the change in the parameters of the system in time (time factor), assuming the decomposition of the process in time to obtain the optimal schedule for the implementation of FPA reproduction.

12. Integrativity is to build an integrated plan, the criterion of which is consistent with the criteria of private plans obtained as a result of the implementation of the principle of decomposability of the system of plans.

13. Accuracy is the development of tools, methods and models that adequately reflect the reproduction process of the FPA, taking into account the nature of the information of the most relevant internal and external factors. Implementation of this principle is achieved by increasing the level of certainty of the initial information (improving the accuracy of 
forecasts) and / or using more complex tools and decision-making methods that are consistent with the nature of the input information (simulation models, stochastic models, etc.).

14. Adaptability is the ability of the plan of FPA reproduction to adapt to changes in factors of the external and internal environment, characterized by uncertainty.

15. Identity is the need to bring the alternatives under consideration (FPA reproduction options) to a comparable species when assessing their comparative effectiveness.

16. Efficiency the need in the process of innovative reproduction of FPA to reduce the cost per unit of output and increase labor productivity.

17. Balance indicates the need to ensure in the process of reproduction the balance of the capacity of the interconnected groups of equipment, sections and shops, as well as a balanced load of equipment and workplaces.

\section{Conclusion}

The proposed principles, in our opinion, largely solve the methodological problems of strategic planning of innovative FPA reproduction of the RSI enterprises.

\section{References}

1. Strategy for the development of the rocket and space industry for the period up to 2015 (Extract). TS VPK: [website]. URL: http://www.vpk.ru/cgibin/cis/w3.cgi/CMS/Item/2540031 (date accessed: 07.06.2013).

2. A.A. Boyko, Methods of Strategic Planning for Innovative Reproduction of Basic Production Assets, Bulletin of the Siberian State Aerospace University Academician M.F. Reshetnev. v. 5(38), p.160-165 (2011)

3. Decree of the Government of the Russian Federation No. 1662-r dated November 17, 2008 (as amended on 08.08.2009) "On the Concept of Long-Term Social and Economic Development of the Russian Federation for the Period to 2020" (together with the "Concept of Long-Term Social and Economic Development of the Russian Federation for the period up to 2020 "). ConsultantPlus: [website]. URL: http://base.consultant.ru/cons/cgi/online.cgi?req $=$ doc;base $=\mathrm{LAW} ; \mathrm{n}=90601$ (date accessed: 07.06.2013).

4. S. A. Agarkov, E. S. Kuznetsova, M. O. Gryaznov, Innovation management and state innovation policy (Academiya Istesvonania, 2011)

5. V. G. Medynsky, Innovation Management (INFRA-M, 2012)

6. P.A. Fatkhutdinov, Innovation management, 6th edition, correction and additions (Peter. S., 2008)

7. M. M. Alekseeva, Business Planning (Finance and Statistics, 2005)

8. V. I. Borisisevich, G.A. Kandaurova, N. N. Kandaurov and etc., Forecasting and planning of the economy, Study Manual / B. I. Borisevich,; under public editing. B. I. Borysiewicz, G. A. Kandaurova (Ecoprespectiva, 2009)

9. A. I. Ilyin, Planning in the enterprise: Study Manual 9th edition (Novoe Znanie, 2011)

10. E. E. Rumyantseva, New Economic Encyclopedia (INFRA-M, 2005)

11. A.A. Boyko, The concept of strategic planning for the reproduction of fixed assets of enterprises of the rocket and space industry, v. 70, p.22 (2013) 
12. A.A. Boyko, Methods of planning the reproduction of fixed productive assets, Reshetnevsky readings, v. 2(17), p.341-342 (2013)

13. A.A. Boyko, Methodological principles of planning of innovative reproduction of the basic production assets of enterprises of the rocket and space industry, Bulletin of the Siberian State Aerospace University. Academician M.F. Reshetneva, v. 4(44), p.194198 (2012)

14. G.S. Mikhalev, A.A. Boyko, Choice and implementation of the variant of reproduction of the basic production assets of machine-building enterprises, monograph, Feder. Education Agency, Sib. state. aerospace. un-t them. acad. M. F. Reshetnev (2005)

15. A.A. Boyko, Methods of choosing the variant of reproduction of the basic production assets of machine-building enterprises, thesis for the degree of candidate of economic sciences, Krasnoyarsk (1997)

16. A.A. Boyko, E.S. Rybakova, Problems of reproduction of the basic production assets of enterprises of the machine-building complex, Problems of Mechanical Engineering and Automation, v. 2, p. 19-26 (2007) 